\title{
INFLUENCE OF THE SUBSTRATE HARDNESS AND FRACTURE TOUGHNESS ON THE DYNAMIC WEAR PROPERTIES OF COATED TOOL STEELS
}

\author{
VPLIV TRDOTE IN LOMNE ŽILAVOSTI PODLAGE NA \\ DINAMIČNE OBRABNE LASTNOSTI OPLAŠČENEGA \\ ORODNEGA JEKLA
}

\author{
Marko Sedlaček $^{1 *}$, Barbara Šetina Batič ${ }^{1}$, Damir Česnik ${ }^{2}$, Bojan Podgornik ${ }^{1}$ \\ ${ }^{1}$ Institute of Metals and Technology, Lepi pot 11, 1000 Ljubljana, Slovenia \\ ${ }^{2}$ Hidria Rotomatika d.o.o., Spodnja Kanomlja 23, 5281 Spodnja Idrija, Slovenia \\ Prejem rokopisa - received: 2018-11-13; sprejem za objavo - accepted for publication: 2019-03-11
}

doi:10.17222/mit.2018.242

\begin{abstract}
The aim of this work was to determine the impact of various heat-treatment processes and parameters on the substrate hardness and fracture toughness combination and subsequently on the wear properties and subsurface deformation of coated tool steel under dynamic impact loading.

Powder-metallurgy steels used as a substrate material were vacuum heat treated under six different conditions and combined with deep cryogenic treatment and nitriding with the aim to modify the hardness and fracture toughness. A TiAlN monolayer with $2-\mu \mathrm{m}$ thickness was used for all the substrates. In order to evaluate the impact failure of the coating a ball-on-plate impact fatigue test was designed and used. It was shown that the use of a cryogenic treatment can increase the fracture toughness from $10 \%$ up to $67 \%$ while maintaining the same hardness for some cold-work tool steels, when on others it can have a negative effect. Regarding the static load-carrying capacity, the most important feature of the substrate is its hardness, which at working hardness of 63-64 HRc already provides good static load-carrying capacity of the coated substrate. The increased fracture toughness achieved by the deep cryogenic treatment can at very high and/or very low hardness of the substrate have a negative impact on the dynamic wear properties of the coated surfaces. On the other hand, in the case of vacuum heat treatment that ensures an adequate working hardness of 63-64 HRc, the deep cryogenic treatment improves the impact wear resistance of coated surfaces.

Keywords: heat treatment, fracture toughness, hardness, wear, hard-coating

Cilj raziskave je bil določiti vpliv različnih toplotnih obdelav in parametrov na trdoto in lomno žilavost ter posledično na obrabno odpornost in podpovršinsko deformacijo oplaščenih orodnih jekel pri dinamičnem udarnem obremenjevanju.

Jekla, izdelana na osnovi prašne metalurgije, so bila toplotno obdelana s šestimi različnimi parametri toplotne obdelave $v$ kombinaciji s kriogenskim podhlajevanjem in nitriranjem z namenom spreminjati njihovo trdoto in lomno žilavost. Na jekla je bila nanešena trda prevleka TiAlN z debelino $2 \mu \mathrm{m}$. Da bi ocenili odpornost prevlečenega jekla na udarno obremenjevanje so bili načrtovani in izvedeni udarni testi s pomočjo kroglice. Rezultati so pokazali, da lahko pri nekaterih jeklih kriogensko podhlajevanje poveča lomno žilavost od $10 \%$ do $67 \%$ ob nespremenjeni trdoti. Najpomembnejša lastnost podlage je njena trdota, ki pri trdoti 63-64 HRc že zagotavlja dobro statično nosilnost oplaščene podlage. Povečana lomna žilavost, dosežena z globoko kriogensko obdelavo, lahko pri zelo visoki in/ali zelo nizki trdoti podlage negativno vpliva na dinamične obrabne lastnosti oplaščenih površin. Po drugi strani pa, v primeru toplotne obdelave, ki zagotavlja zadostno trdoto (63-64 HRc), globoka kriogenska obdelava izboljša udarno obrabno odpornost oplaščenih površin.

Ključne besede: toplotna obdelava, lomna žilavost, trdota, obraba, trda prevleka
\end{abstract}

\section{INTRODUCTION}

The metal-processing industry is constantly faced with demands for greater productivity and lower costs, which requires better sustainability of tools and the use of different material-modification techniques. With the use of new materials (HSS and AHSS), tools are even more exposed to very demanding contact conditions, including high impact loads, high contact pressures, elevated temperatures and high wear. The processing of harder materials puts a lot of stress on the contact surfaces, exposing them to a combination of cyclic, mechanical, chemical and tribological loads, which can

*Corresponding author's e-mail:

marko.sedlacek@imt.si result in fatigue, chipping and wear of the tool. ${ }^{1-2}$ In order to face all those problems a variety of approaches, from changing tool material and heat treatment, different geometry, design, manufacturing parameters and work material, can be applied..$^{3-4}$ Although each of those parameters has its role, the largest impact comes from the tool material and its microstructure. The most used material in precision punching tools is nowadays based on powder-metallurgy $(\mathrm{P} / \mathrm{M})$ steels. $\mathrm{P} / \mathrm{M}$ steels, which have fine and uniform microstructure, in some cases could have a higher toughness but lower abrasion resistance than conventionally produced steel. ${ }^{5}$ Tools are normally heat treated to obtain a microstructure of tempered martensite in a uniform distribution of carbides, which enable sufficient fracture toughness at the working 
hardness and acceptable wear resistance. ${ }^{6}$ A problem with lower abrasion resistance is usually solved by the use of techniques of surface modification, and to a limited extent also with the application of hard coat ings. $^{7-9}$ It is illusory to expect that merely hard coating deposition will solve the abrasion resistance. Since applied hard coatings are normally very thin and brittle, the majority of the contact load is carried by the substrate material. In order to achieve the right load-carrying capacity of the substrate material, it must reflect high hardness and at the same time, sufficient fracture toughness. This can be achieved by using different heat-treatment processes and parameters, which have an influence on the microstructure of a tool steel and therefore on its mechanical and tribological properties. ${ }^{10}$ Especially vacuum heat treatment, deep cryogenic treatment and pulse plasma nitriding have shown very positive effects on the performance of high-speed steels. ${ }^{11-15}$ If the substrate is not hard enough to carry the load, elastic and plastic deformation will occur in the substrate under the contact, leading to the failure of the coating. Therefore, on a harder substrate, a higher contact loading can be applied without the coating failure due to fracture, spalling or delamination. ${ }^{16}$ However, the fracture toughness and resistance to crack initiation and propagation of the substrate are equally if not more important than the hardness and wear resistance. ${ }^{17-20}$ Combining those properties is therefore essential to ensure the load-carrying capacity and wear resistance of the substrate.

The aim of our work was to investigate the influence of different vacuum heat-treatment parameters, a combination of deep cryogenic treatment, nitriding and $\mathrm{HRc} / \mathrm{K}_{\mathrm{Ic}}$ ratio on the dynamic wear properties of two coated cold-work tool steels and one high-speed steel.

\section{EXPERIMENTAL PART}

\subsection{Material, heat treatment and coating}

Three different materials produced by powder-metallurgy methods were used for this investigation. Two materials denoted as A and B were from cold-work tool steel, and one from high-speed steel, denoted as C. The chemical composition is shown in Table 1.

Table 1: Chemical composition (in $w / \%$ ) of used powder-metallurgy steels

\begin{tabular}{|c|c|c|c|c|c|c|c|c|}
\hline Material & $\mathrm{C}$ & $\mathrm{Si}$ & $\mathrm{Mn}$ & $\mathrm{Cr}$ & $\mathrm{Mo}$ & $\mathrm{V}$ & $\mathrm{W}$ & $\mathrm{Co}$ \\
\hline A & 0.85 & 0.55 & 0.40 & 4.35 & 2.80 & 2.10 & 2.55 & 4.50 \\
\hline $\mathrm{B}$ & 2.47 & 0.55 & 0.40 & 4.20 & 3.80 & 9.00 & 1.00 & 2.00 \\
\hline C & 1.64 & 0.60 & 0.30 & 4.80 & 2.00 & 4.80 & 10.40 & 8.00 \\
\hline
\end{tabular}

In order to give three different relationships between the fracture toughness $\left(\mathrm{K}_{\mathrm{I}} \mathrm{c}\right)$ and the hardness (HRC), the vacuum heat-treatment parameters were chosen to achieve the maximum hardness of the substrate (denoted as treatment 1), the maximum toughness hardness (denoted as treatment 2) and a maximum ratio of fracture toughness at the working range hardness (denoted as treatment 3). The heat-treatment parameters were chosen according to the existing tempering charts.

Additionally, some heat treatments of samples A, B and $C$ were combined with a deep cryogenic treatment in such a way that the samples were first heated to the austenitizing temperature, and hardened with a stream of gaseous nitrogen at a pressure of 5 bar followed by immediate controlled sub-cooling of the material in liquid nitrogen at a temperature of $-196{ }^{\circ} \mathrm{C}$ for $25 \mathrm{~h}$. On the other hand, for samples $\mathrm{C}$ a combination of vacuum heat treatment and plasma nitriding was also chosen and denoted with the letter $\mathrm{N}$. Nitriding in plasma was carried out for $2 \mathrm{~h}$ at $520{ }^{\circ} \mathrm{C}$ in $5 \% \mathrm{~N}_{2}-95 \% \mathrm{H}_{2}$. The temperatures, time of austenitization and tempering and

Table 2: Temperatures, time of austenitization and tempering for material A

\begin{tabular}{|c|c|c|c|c|}
\hline \multirow[b]{2}{*}{ Treatment } & \multicolumn{4}{|c|}{ Heat treatment } \\
\hline & Austenitization & Hardening & Undercooling & Tempering \\
\hline A1 & $1130^{\circ} \mathrm{C} / 6 \mathrm{~min}$ & $\mathrm{~N}_{2}, 5$ bar & - & $2 \times 2 \mathrm{~h} / 520^{\circ} \mathrm{C}+1 \times 2 \mathrm{~h} / 500{ }^{\circ} \mathrm{C}$ \\
\hline A2 & $1070{ }^{\circ} \mathrm{C} / 20 \mathrm{~min}$ & $\mathrm{~N}_{2}, 5$ bar & - & $2 \times 2 \mathrm{~h} / 585^{\circ} \mathrm{C}+1 \times 2 \mathrm{~h} / 555^{\circ} \mathrm{C}$ \\
\hline A3 & $1100{ }^{\circ} \mathrm{C} / 20 \mathrm{~min}$ & $\mathrm{~N}_{2}, 5$ bar & - & $2 \times 2 \mathrm{~h} / 500^{\circ} \mathrm{C}+1 \times 2 \mathrm{~h} / 470{ }^{\circ} \mathrm{C}$ \\
\hline A1-U & $1130{ }^{\circ} \mathrm{C} / 6 \mathrm{~min}$ & $\mathrm{~N}_{2}, 5$ bar & $-196^{\circ} \mathrm{C} / 25 \mathrm{~h}$ & $1 \times 2 \mathrm{~h} / 520{ }^{\circ} \mathrm{C}$ \\
\hline A2-U & $1070{ }^{\circ} \mathrm{C} / 20 \mathrm{~min}$ & $\mathrm{~N}_{2}, 5$ bar & $-196^{\circ} \mathrm{C} / 25 \mathrm{~h}$ & $1 \times 2 \mathrm{~h} / 585^{\circ} \mathrm{C}$ \\
\hline A3-U & $1100{ }^{\circ} \mathrm{C} / 20 \mathrm{~min}$ & $\mathrm{~N}_{2}, 5$ bar & $-196^{\circ} \mathrm{C} / 25 \mathrm{~h}$ & $1 \times 2 \mathrm{~h} / 500{ }^{\circ} \mathrm{C}$ \\
\hline
\end{tabular}

Table 3: Temperatures, time of austenitization and tempering for material B

\begin{tabular}{|c|c|c|c|c|}
\hline & \multicolumn{4}{|c|}{ Heat treatment } \\
\hline Treatment & Austenitization & Hardening & Undercooling & Tempering \\
\hline $\mathrm{B} 1$ & $1180^{\circ} \mathrm{C} / 6 \mathrm{~min}$ & $\mathrm{~N}_{2}, 5 \mathrm{bar}$ & - & $2 \times 2 \mathrm{~h} / 540{ }^{\circ} \mathrm{C}+1 \times 2 \mathrm{~h} / 510{ }^{\circ} \mathrm{C}$ \\
\hline $\mathrm{B} 2$ & $1180^{\circ} \mathrm{C} / 6 \mathrm{~min}$ & $\mathrm{~N}_{2}, 5 \mathrm{bar}$ & - & $2 \times 2 \mathrm{~h} / 500{ }^{\circ} \mathrm{C}+1 \times 2 \mathrm{~h} / 470{ }^{\circ} \mathrm{C}$ \\
\hline $\mathrm{B} 3$ & $1180^{\circ} \mathrm{C} / 6 \mathrm{~min}$ & $\mathrm{~N}_{2}, 5 \mathrm{bar}+1 \times 2 \mathrm{~h} / 530^{\circ} \mathrm{C}$ \\
\hline $\mathrm{B} 1-\mathrm{U}$ & $1180^{\circ} \mathrm{C} / 6 \mathrm{~min}$ & $\mathrm{~N}_{2}, 5 \mathrm{bar}$ & $-196^{\circ} \mathrm{C} / 25 \mathrm{~h}$ & $1 \times 2 \mathrm{~h} / 540^{\circ} \mathrm{C}$ \\
\hline $\mathrm{B} 2-\mathrm{U}$ & $1180^{\circ} \mathrm{C} / 6 \mathrm{~min}$ & $\mathrm{~N}_{2}, 5 \mathrm{bar}$ & $-196^{\circ} \mathrm{C} / 25 \mathrm{~h}$ & $1 \times 2 \mathrm{~h} / 500^{\circ} \mathrm{C}$ \\
\hline $\mathrm{B} 3-\mathrm{U}$ & $1180^{\circ} \mathrm{C} / 6 \mathrm{~min}$ & $\mathrm{~N}_{2}, 5 \mathrm{bar}$ & $-196^{\circ} \mathrm{C} / 25 \mathrm{~h}$ & $1 \times 2 \mathrm{~h} / 560^{\circ} \mathrm{C}$ \\
\hline
\end{tabular}


M. SEDLAČEK et al.: INFLUENCE OF THE SUBSTRATE HARDNESS AND FRACTURE TOUGHNESS ...

Table 4: Temperatures, time of austenitization and tempering for material C

\begin{tabular}{|c|c|c|c|c|c|}
\hline & \multicolumn{5}{|c|}{ Heat treatment } \\
\hline Treatment & Austenitization & Hardening & Undercooling & Tempering & Nitriding \\
\hline $\mathrm{C} 1$ & $1180{ }^{\circ} \mathrm{C} / 2 \mathrm{~min}$ & $\mathrm{~N}_{2}, 5$ bar & - & $2 \times 2 \mathrm{~h} / 530{ }^{\circ} \mathrm{C}+1 \times 2 \mathrm{~h} / 500{ }^{\circ} \mathrm{C}$ & - \\
\hline $\mathrm{C} 2$ & $1030^{\circ} \mathrm{C} / 20 \mathrm{~min}$ & $\mathrm{~N}_{2}, 5$ bar & - & $2 \times 2 \mathrm{~h} / 570{ }^{\circ} \mathrm{C}+1 \times 2 \mathrm{~h} / 540^{\circ} \mathrm{C}$ & - \\
\hline C3 & $1100{ }^{\circ} \mathrm{C} / 20 \mathrm{~min}$ & $\mathrm{~N}_{2}, 5$ bar & - & $2 \times 2 \mathrm{~h} / 560{ }^{\circ} \mathrm{C}+1 \times 2 \mathrm{~h} / 530^{\circ} \mathrm{C}$ & - \\
\hline $\mathrm{C} 1-\mathrm{U}$ & $1180^{\circ} \mathrm{C} / 2 \mathrm{~min}$ & $\mathrm{~N}_{2}, 5$ bar & $-196^{\circ} \mathrm{C} / 25 \mathrm{~h}$ & $1 \times 2 \mathrm{~h} / 530$ & - \\
\hline $\mathrm{C} 2-\mathrm{U}$ & $1030{ }^{\circ} \mathrm{C} / 20 \mathrm{~min}$ & $\mathrm{~N}_{2}, 5$ bar & $-196^{\circ} \mathrm{C} / 25 \mathrm{~h}$ & $1 \times 2 \mathrm{~h} / 570^{\circ} \mathrm{C}$ & - \\
\hline C3-U & $1100{ }^{\circ} \mathrm{C} / 20 \mathrm{~min}$ & $\mathrm{~N}_{2}, 5$ bar & $-196^{\circ} \mathrm{C} / 25 \mathrm{~h}$ & $1 \times 2 \mathrm{~h} / 560{ }^{\circ} \mathrm{C}$ & - \\
\hline $\mathrm{C} 1-\mathrm{N}$ & $1180^{\circ} \mathrm{C} / 2 \mathrm{~min}$ & $\mathrm{~N}_{2}, 5$ bar & - & $2 \times 2 \mathrm{~h} / 530^{\circ} \mathrm{C}$ & $2 \mathrm{~h} / 520{ }^{\circ} \mathrm{C} 5 \% \mathrm{~N}_{2}-95 \% \mathrm{H}_{2}$ \\
\hline $\mathrm{C} 2-\mathrm{N}$ & $1030{ }^{\circ} \mathrm{C} / 20 \mathrm{~min}$ & $\mathrm{~N}_{2}, 5$ bar & - & $2 \times 2 \mathrm{~h} / 570{ }^{\circ} \mathrm{C}$ & $2 \mathrm{~h} / 520{ }^{\circ} \mathrm{C} 5 \% \mathrm{~N}_{2}-95 \% \mathrm{H}_{2}$ \\
\hline $\mathrm{C} 3-\mathrm{N}$ & $1100{ }^{\circ} \mathrm{C} / 20 \mathrm{~min}$ & $\mathrm{~N}_{2}, 5$ bar & - & $2 \times 2 \mathrm{~h} / 560^{\circ} \mathrm{C}$ & $2 \mathrm{~h} / 520{ }^{\circ} \mathrm{C} 5 \% \mathrm{~N}_{2}-95 \% \mathrm{H}_{2}$ \\
\hline
\end{tabular}

combinations of treatments for material A are presented in Table 2, for material B in Table 3 and for material C in Table 4.

As a hard protective coating a TiAlN monolayer with a hardness of 3300 HV0.05 (measured by nano-indentation - Fischerscope H100C) was deposited using a PVD procedure. The coating thickness was approximately $2 \mu \mathrm{m}$ and was deposited on the substrate at a temperature of $\approx 450{ }^{\circ} \mathrm{C}$ on polished heat-treated samples $\left(R_{\mathrm{a}}=0.05\right.$ $-0.10 \mu \mathrm{m})$ with dimensions of $(20 \times 20 \times 8) \mathrm{mm}$. Details of the coating deposition process are given in the paper of M. Panjan et al. ${ }^{21}$

\subsection{Fracture toughness, hardness, coating adhesion and impact wear}

The fracture toughness was determined with the use of round, circumferentially notched tensile-test specimens and a fatigue pre-crack in the root of the notch made in the rotating-bending mode before the heat treatment. ${ }^{22-23}$ The fracture toughness is calculated based on the measured rapture force and diameter of the instantly fractured part of the specimen. The measurements of fracture toughness were conducted on at least 12 parallel $K_{\mathrm{Ic}}$-specimens. Rockwell $\mathrm{C}$ hardness measurements using an Instron B2000 machine were made on each $K_{\text {Ic }}$ test specimen. For each sample up to six measurements were made circumferentially on the widest part of the $K_{\text {Ic }}$ test specimen.

Adhesion and static load-carrying capacity of coatings applied on the different vacuum heat-treated substrates were determined using the Rockwell $\mathrm{C}$ indentation test. The test is considered a very quick and easy test of coatings adhesion, which is defined with the standard VDI $3198 .^{24}$

In order to evaluate the influence of different vacuum heat treatments and the $\mathrm{HRc} / K_{\mathrm{Ic}}$ ratio of the substrate on dynamic impact wear resistance of the coating ball-onplate impact wear test was designed. For this purpose an Instron 8802 dynamic testing machine was used. In the dynamic impact tests carried out at room temperature, a tungsten carbide ball with a diameter of $32 \mathrm{~mm}$ was used as a counterpart, ensuring that most of the wear occurred on the coated sample. Due to the configuration of the machine the ball was fixed during testing, while the coated plate $(20 \mathrm{~mm} \times 20 \mathrm{~mm} \times 8 \mathrm{~mm})$ was impacting against the stationary ball at a frequency of $30 \mathrm{~Hz}$, as shown in Figure 1. During the testing the impacting force was changing in a sinusoidal wave and reached a peak compressive value of $5.5 \mathrm{kN}$, which corresponds to the contact pressure of $3.5 \mathrm{GPa}$. In the lowest position the ball and the plate were completely separated with a gap of $\approx 0.5 \mathrm{~mm}$. The duration of the test was limited to 300,000 cycles. For each substrate at least three repeated tests were performed. To avoid wear and transfer of the tungsten carbide to the coating surface a new ball and lithium grease were used for each test. After the test, the wear of the coating was measured using optical profilometry with an Alicona Infinitefocus G4.

\section{RESULTS AND DISCUSSION}

\subsection{Hardness and fracture toughness}

The results of the hardness and fracture toughness for two different cold-work tool steel (denoted as A and B) and one from high-speed steel (denoted as C) are presented in Figures 2 to 4. Figure 2 presents the influence of different heat treatments on the hardness and the fracture toughness of the cold-work tool steel with a lower content of $\mathrm{C}$ and a higher content of W. It can be seen that in the case of the highest austenitizing temperature $\left(\mathrm{A} 1 ; T_{\mathrm{A}}=1130{ }^{\circ} \mathrm{C}\right.$, ) a hardness of $65.8 \mathrm{HRc}$ and a fracture toughness $K_{\mathrm{Ic}}=6.1 \mathrm{MPa} \cdot \mathrm{m}^{1 / 2}$ were achieved. By reducing the austenitization temperature $\left(\mathrm{A} 2 ; T_{\mathrm{A}}=\right.$ $1070{ }^{\circ} \mathrm{C}$ ), where the maximum fracture toughness was expected, a fracture toughness $K_{\mathrm{Ic}}=12.7 \mathrm{MPa} \cdot \mathrm{m}^{1 / 2}$ and a

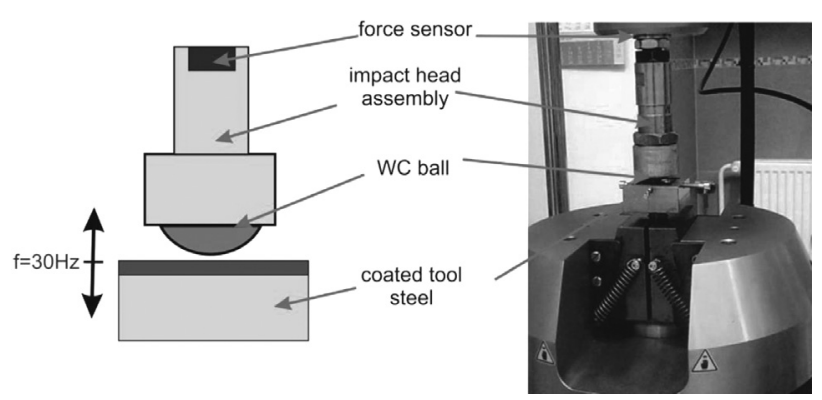

Figure 1: Schematic representation and actual impact dynamic testing 
hardness of 59.3 HRc were obtained. In the case of the heat treatment where the optimal combination of working hardness and fracture toughness was expected (A3; $\left.T_{\mathrm{A}}=1100{ }^{\circ} \mathrm{C}\right)$, a hardness of $63.9 \mathrm{HRc}$ and a fracture toughness $K_{\text {Ic }}=10.1-10.2 \mathrm{MPa} \cdot \mathrm{m}^{1 / 2}$ were achieved.

Combining a vacuum heat treatment with a deep cryogenic treatment in liquid nitrogen for $25 \mathrm{~h}$ led to an increase in the fracture toughness at practically the same hardness. In the case of the first series of samples hardened at the highest austenitizing temperature (A1U), at practically the same hardness of $65.0 \mathrm{HRc}$, a 25-hour deep cryogenic treatment in liquid nitrogen increased the fracture toughness from 6.1 $\mathrm{MPa}$ to $10.4 \mathrm{MPa}$. For the second series of samples with the lowest austenitizing temperature (A2U), a 25-hour deep cryogenic treatment in liquid nitrogen led to an approximately $12 \%$ increase in fracture toughness, from $12.7 \mathrm{MPa} \cdot \mathrm{m}^{1 / 2}$ to 14.2 $\mathrm{MPa} \cdot \mathrm{m}^{1 / 2}$, at an even higher hardness of $59.5 \mathrm{HRc}$. For the optimal combination of fracture toughness at the working hardness (treatment $\mathrm{A} 3 \mathrm{U}$ ), the deep cryogenic treatment resulted in a $16 \%$ improvement in the fracture toughness, increasing it from $11.0 \mathrm{MPa} \cdot \mathrm{m}^{1 / 2}$ to 12.8 $\mathrm{MPa} \cdot \mathrm{m}^{1 / 2}$ and in a slight increase in hardness. The effect of the deep cryogenic treatment on the change in hardness and fracture toughness, including scatter, is graphically displayed in a combined $\mathrm{HRc} / K_{\mathrm{Ic}}$ diagram in Figure 2.

Despite the intensive research on cold-work and high-speed steels that has shown that a deep cryogenic treatment can lead to an improved material performance, including fracture toughness and wear resistance, the cause is still not fully understood, since the authors reported contradictory results. P. Baldissera et al. suggest that the improvement obtained by deep cryogenic treatment is mainly contributed to the complete elimination of retained austenite and the formation of very small carbides dispersed in the tempered martensitic structure. ${ }^{25}$ On the other hand, G. Gavriljuk et al. reported that the full austenite-to-martensite transformation does not occur in high-carbon steels, with the martensitic transformation at low temperature being accompanied by plastic deformation of virgin martensite. ${ }^{26}$ According to the B. Podgornik et al. the improved fracture toughness is a result of the plastic deformation of the primary martensite combined with a reduced amount of dissolved carbon in the martensite and finer and more homogeneous carbides precipitation. ${ }^{27}$

The same as for the cold-work tool steel A, was also for the cold work tool steel B with a higher content of C and $\mathrm{V}$, heat treatment determined so it resulted in the highest hardness (B1), highest fracture toughness (B2) and optimal combination of fracture toughness at the working hardness (treatment B3). With the highest austenitizing temperature (B1) a hardness of $66.0 \mathrm{HRc}$ and a fracture toughness of $11.2 \mathrm{MPa} \cdot \mathrm{m}^{1 / 2}$ were reached. With the same austenitizing temperature but lower tempering temperature (B2) a maximum fracture toughness of 15.0

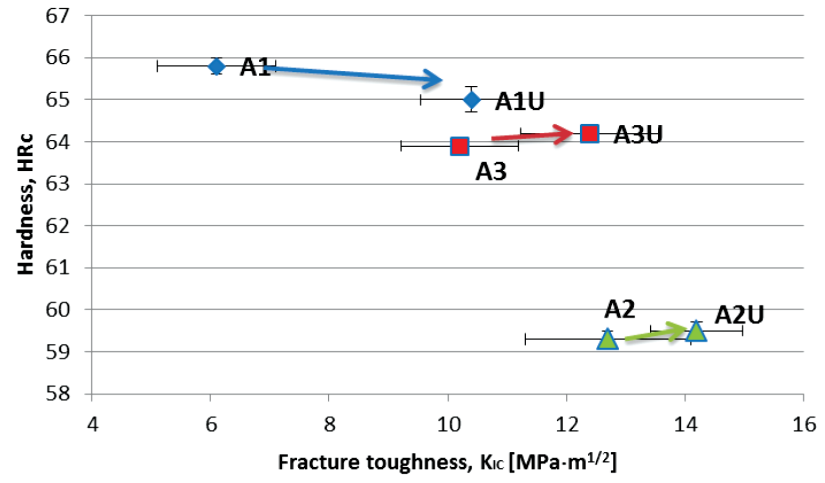

Figure 2: Effect of deep cryogenic treatment on the change in hardness and fracture toughness of cold-work tool steel A

$\mathrm{MPa} \cdot \mathrm{m}^{1 / 2}$ and a hardness of $64.6 \mathrm{HRc}$ were achieved. A hardness of $64.6 \mathrm{HRc}$ and a toughness of $6.10 \mathrm{MPa} \cdot \mathrm{m}^{1 / 2}$ were achieved with treatment B3.

For material B, combining vacuum heat treatment with a deep cryogenic treatment in liquid nitrogen for $25 \mathrm{~h}$ did not lead to an increase in the fracture toughness. For treatment B1U the hardness decreased by $2.5 \%$ on 64.3 HRc and the fracture toughness up to $10 \%$, to $10 \mathrm{MPa} \cdot \mathrm{m}^{1 / 2}$. In the case of treatment $\mathrm{B} 2 \mathrm{U}$, where the initial fracture toughness was the highest, a $40 \%$ decrease was recorded $\left(8.9 \mathrm{MPa} \cdot \mathrm{m}^{1 / 2}\right)$ when combining a heat treatment with a cryogenic treatment. Treatment B3U, on the other hand, resulted in a slight increase in the fracture toughness from $10.6 \mathrm{MPa} \cdot \mathrm{m}^{1 / 2}$ to $11.5 \mathrm{MPa} \cdot \mathrm{m}^{1 / 2}$, but it decreases the hardness to only 63 HRc. As reported in the paper of B. Podgornik et al., a high volume fraction of undissolved eutectic carbides (18-20\%) was observed and related to the neglected effect of plastic deformation of the primary martensite during the deep cryogenic treatment. ${ }^{27}$ The undissolved eutectic carbides are mainly of more stable MC type, probably leading to a change in the precipitation type and kinetics, which might lead to impairment of the properties when including a deep cryogenic treatment. ${ }^{27}$ The results are shown in Figure 3.

For high-speed steel it can be seen (Figure 4) that in the case of the highest austenitizing temperature $(\mathrm{C} 1$; $T_{\mathrm{A}}=1180{ }^{\circ} \mathrm{C}$, ) a hardness of $68.2 \mathrm{HRc}$ and a fracture toughness $K_{\mathrm{Ic}}=7.6 \mathrm{MPa} \cdot \mathrm{m}^{1 / 2}$ were achieved. By reduc-

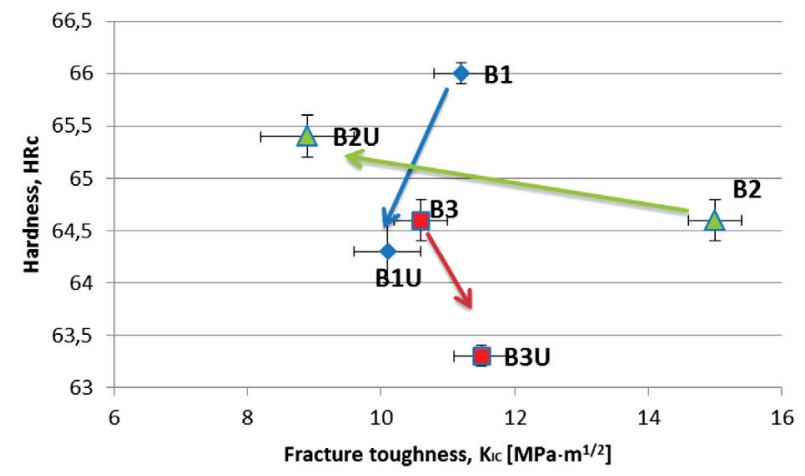

Figure 3: Effect of deep cryogenic treatment on the change in hardness and fracture toughness of cold-work tool steel B 
ing the austenitization temperature $\left(\mathrm{C} 2 ; T_{\mathrm{A}}=1030{ }^{\circ} \mathrm{C}\right)$, where the maximum fracture toughness was expected, a fracture toughness $K_{\mathrm{Ic}}=10.0 \mathrm{MPa} \cdot \mathrm{m}^{1 / 2}$ and a hardness of $60.8 \mathrm{HRc}$ were obtained. In the case of the heat treatment where the optimal combination of working hardness and fracture toughness was expected $\left(\mathrm{C} 3 ; T_{\mathrm{A}}=\right.$ $1100{ }^{\circ} \mathrm{C}$ ), a hardness of $64.1 \mathrm{HRc}$ and a fracture toughness $K_{\mathrm{Ic}}=8.7 \mathrm{MPa} \cdot \mathrm{m}^{1 / 2}$ were achieved.

Combining a vacuum heat treatment with a deep cryogenic treatment in liquid nitrogen for $25 \mathrm{~h}$ did not lead to a significant increase in the fracture toughness or hardness. In the case of the first series of samples hardened at the highest austenitizing temperature $(\mathrm{C} 1 \mathrm{U})$, at slightly lower hardness $67.7 \mathrm{HRc}$, a 25 -hour deep cryogenic treatment in liquid nitrogen increased the fracture toughness from $7.6 \mathrm{MPa} \cdot \mathrm{m}^{1 / 2}$ to $8.5 \mathrm{MPa} \cdot \mathrm{m}^{1 / 2}$, which represents a $10 \%$ improvement in the fracture toughness. An even lower change was recorded for the second series of samples with the lowest austenitizing temperature (C2U), where a 25-hour deep cryogenic treatment in liquid nitrogen led to an approximately $4 \%$ increase in the fracture toughness, from $10.0 \mathrm{MPa} \cdot \mathrm{m}^{1 / 2}$ to 10.4 MPa $\cdot \mathrm{m}^{1 / 2}$, at a slightly higher hardness of $61.4 \mathrm{HRc}$. For the optimal combination of fracture toughness at the working hardness (treatment $\mathrm{C} 3 \mathrm{U}$ ), a deep cryogenic treatment resulted in a less than $5 \%$ improvement in the fracture toughness, increasing it from $8.7 \mathrm{MPa} \cdot \mathrm{m}^{1 / 2}$ to 9.1 $\mathrm{MPa} \cdot \mathrm{m}^{1 / 2}$ and in a slight increase in the hardness (from 64.1 HRc to $64.7 \mathrm{HRc}$ ). The effect of the deep cryogenic treatment on the change in the hardness and the fracture toughness is graphically displayed in a combined HRc/ $K_{\text {Ic }}$ diagram in Figure 4. As explained in the paper of Duh et al. the small effect of the deep-cryogenic treatment on the hardness and fracture toughness of steel $\mathrm{C}$ can be attributed to the very small volume fraction of retained austenite in the steel after quenching, but mainly due to the high volume fraction of undissolved eutectic carbides, consequently reducing the amount of martensite matrix and diminishing the effect of the martensite plastic deformation and capturing of the immobile carbon atoms by gliding dislocations during the deep cryogenic treatment. ${ }^{28}$

When combining all three different vacuum heat treatments with plasma nitriding we observed a surface hardness increase. The nitriding diffusion zone has a thickness $\approx 65 \mu \mathrm{m}$. With the samples with the highest austenitizing temperature $(\mathrm{C} 1 \mathrm{~N})$ additional nitriding resulted in an increase of the hardness to $1450 \mathrm{HV}_{0.05}$, wherein the hardness of the base material decreased to $920 \mathrm{HV}_{0.05}, \approx 67.5 \mathrm{HRc}$. For the samples with the lowest austenitizing temperature $(\mathrm{C} 2 \mathrm{~N})$ the hardness increased to $1280 \mathrm{HV}_{0.05}$, while the hardness of the base stayed the same $\left(722 \mathrm{HV}_{0.05}, \approx 61 \mathrm{HRc}\right)$. The same was true for the optimal combination of fracture toughness at the working hardness (treatment $\mathrm{C} 3 \mathrm{~N}$ ), where for the same hardness of the base $\left(804 \mathrm{HV}_{0.05}, \approx 64 \mathrm{HRc}\right)$ the hardness of the surface increased to over $1350 \mathrm{HV}_{0.05}$. The in-

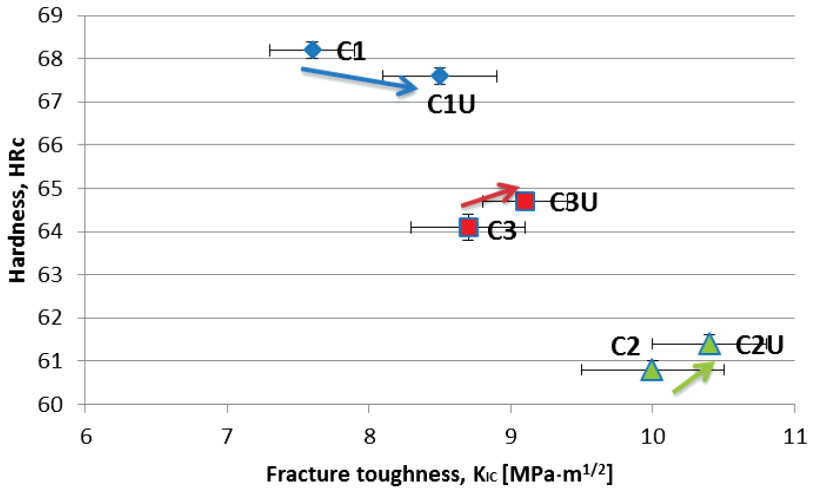

Figure 4: Effect of deep cryogenic treatment on the change in hardness and fracture toughness of high-speed steel C

fluence on the nitriding of the fracture toughness could not be determined, because of the inadequacy of the method with a cylindrical specimen having a notch. From the literature it is known that nitriding deteriorates the ductility of the surface layer. ${ }^{28}$

\subsection{Coating adhesion}

The comparison of the Rockwell $\mathrm{C}$ adhesion test results for a monolayer TiAlN coating deposited on differently vacuum heat-treated substrates is shown in Figures 5 and 6. In general, all the substrates, regardless of the type of vacuum heat treatment used, either combined with a cryogenic treatment or nitriding exhibit
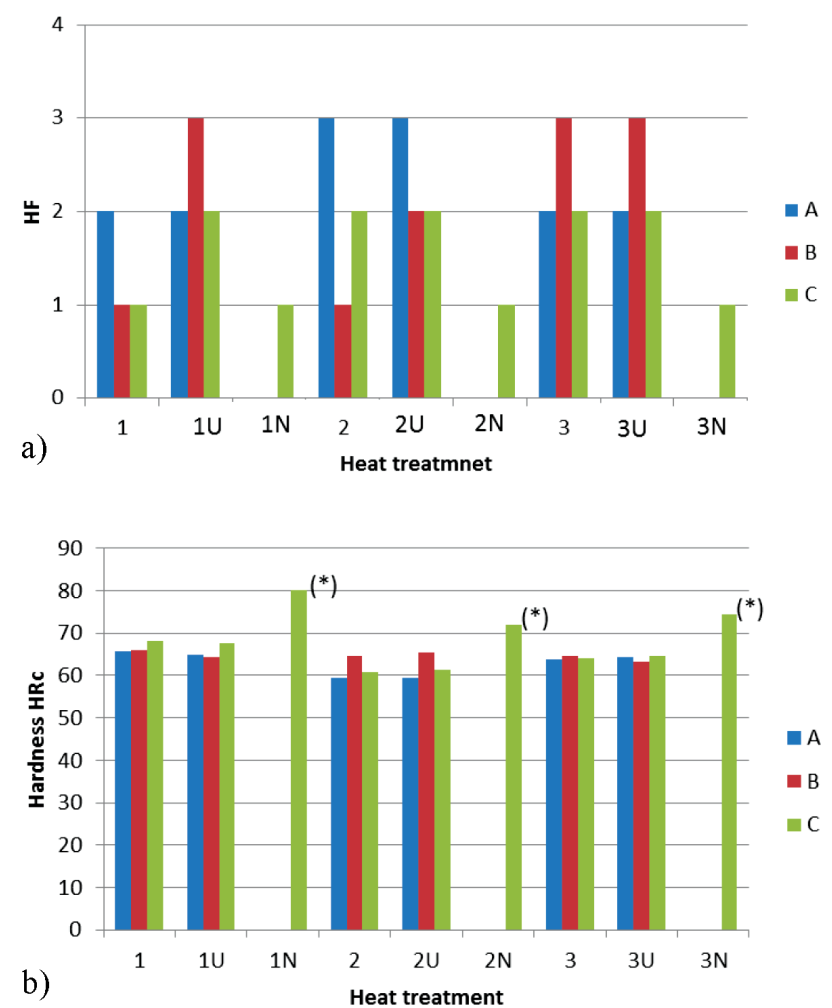

Figure 5: Influence of heat treatment $(1,2,3)$, cryogenic treatment $(\mathrm{U})$, nitriding $(\mathrm{N})$ and used material $(\mathrm{A}, \mathrm{B}, \mathrm{C})$ on: a) coating adhesion, b) hardness $(*)$ - for nitrided samples values are for information only 

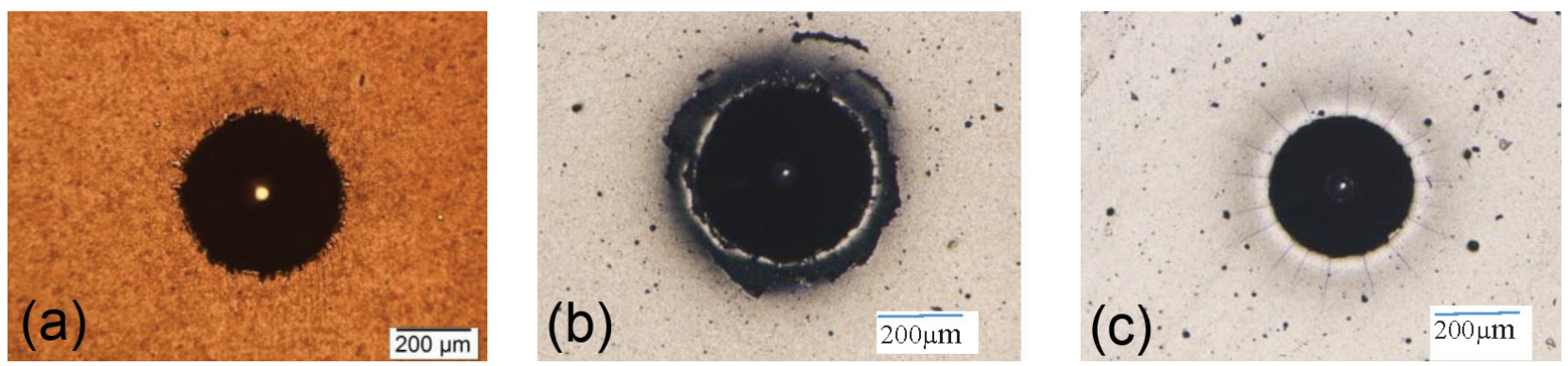

Figure 6: Rockwell C indentation for: a) A1 b) $\mathrm{C} 2$ and c) $\mathrm{C} 1 \mathrm{~N}$

good adhesion (HF1 to HF3). None of the samples reached unacceptable damage level, but there are visible differences between the different vacuum heat treatments, deep cryogenic treatment and nitriding combinations used.

In general, it can be seen that hardness of the substrate material is the main impact factor. When hardness is higher than or equal to $64 \mathrm{HRc}$ (Figure 5b), the adhesion is good with only a network of radial cracks observed around the indentation (Figure 6a). When, on the other hand, the hardness is too low, for cold-work tool steel A and high-speed steel C, also circular cracks and a small coating delamination can be recorded, indicating a too low load-carrying capacity of the steel substrate to be able to support the deposited coating (Figure 6b).

Combining a vacuum heat treatment with a deep cryogenic treatment in liquid nitrogen has no influence on the coating adhesion for cold-work tool steel A. On the other hand, for cold-work tool steel B, with the use of a deep cryogenic treatment, the adhesion slightly deteriorates when the hardness of the substrate is the highest (B1U) and the lowest (B2U). This can be explained with a decrease of the hardness with the use of a deep cryogenic treatment.

The best adhesion of the coating was recorded on cold-work tool steel B and high-speed steel $\mathrm{C}$ with heat treatment 1 and for the high-speed steel $\mathrm{C}$ when the vacuum heat treatment was combined with the nitriding (Figure 6c), indicating that the substrate hardness has the most important role on the adhesion as it provides sufficient load-carrying capacity of the steel substrate to support the top coating. This correlates well with the findings of C. Zhang et al. that the adhesion between the coating and the substrate increases linearly with the increase in the substrate hardness. ${ }^{29}$

In Figure 5b the hardness values for the nitrided samples are given in Rockwell. Those values were converted from the Vickers measurement and are for information only, because the values are out of the conversion range.

\subsection{Impact wear}

In Figure 7a the impact wear properties of the investigated materials are presented in the form of coating wear depth as a function of the different substrate heat treatment. To facilitate the presentation hardness (Figure 7a) and fracture toughness (Figure 7c) as a function of different heat treatments are presented. It can be seen that for all the used materials the hardness of the substrate plays the most important role. It can be seen that the worst wear was recorded when the heat treatment resulted in the lowest hardness (treatment 2), regardless of the used material. The lowest wear was recorded when the heat treatment gave the highest hardness (treatment 1 ), with the only exception being high-speed steel $\mathrm{C}$, where the lowest impact wear was recorded with the vacuum heat treatment that provided the highest fracture toughness at the working hardness (treatment C3; 64.1 $\mathrm{HRc}$ and $K_{\mathrm{Ic}}=8.7 \mathrm{MPa} \cdot \mathrm{m}^{1 / 2}$ ). Treatment $\mathrm{C} 2$, which has the lowest hardness overall, resulted in the highest wear rate among all the investigated samples.

The deep cryogenic treatment, although providing increased fracture toughness, had a negative impact on the coating impact wear resistance when combined with the vacuum heat treatment that provided the maximum hardness (treatment 1) or the maximum fracture toughness (treatment 2), for all the investigated materials. On the other hand, for the cold-work tool steel A the vacuum heat treatment A3, which at working hardness of 63-64 HRc ensures maximum fracture toughness, the deep cryogenic treatment increases both the hardness and the fracture toughness and thus has a positive impact on the dynamic impact wear resistance of the coatings. By simultaneously increasing the hardness and the fracture toughness $\left(64.2 \mathrm{HRc}\right.$ and $\left.K_{\mathrm{Ic}}=12.4 \mathrm{MPa} \cdot \mathrm{m}^{1 / 2}\right)$, the wear of the coating decreased by $\approx 30 \%$ and became comparable to the case of the vacuum heat treatment A1.

For high-speed steel $\mathrm{C}$, combining the vacuum heat treatment with the nitriding has a positive effect on the impact wear properties. Introducing nitriding drastically decreased the impact wear compared to the heat treated with or without the deep cryogenic treatment ( $\mathrm{C}$ and C_U), which can be attributed to the influence of the increased hardness. When comparing the influence of the hardness on the impact wear of the nitride samples, the influence of hardness is still visible. The vacuum heat treatment that resulted in the highest hardness $(\mathrm{C} 1 \mathrm{~N})$, resulted in the lowest impact wear, and the vacuum heat 

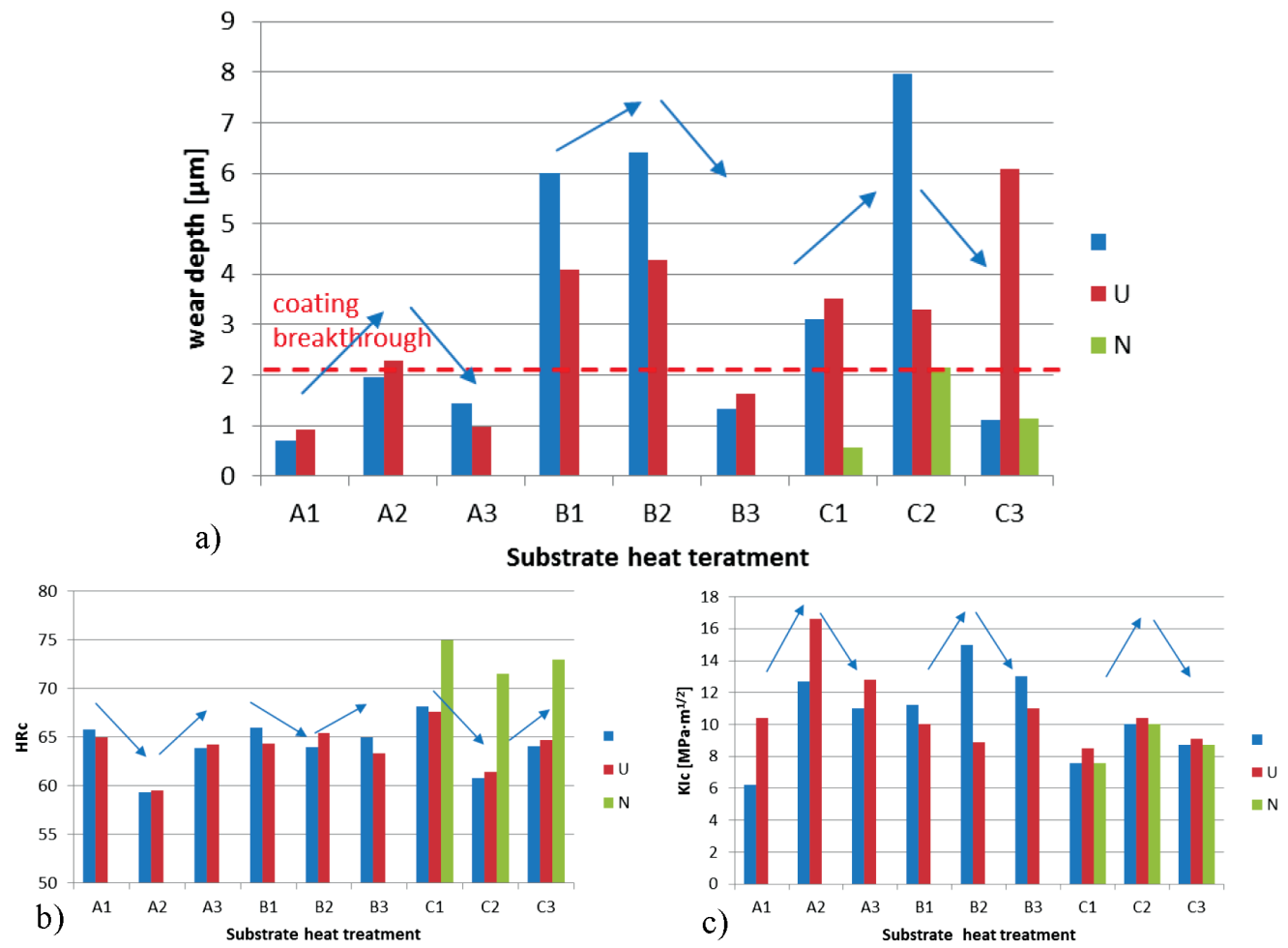

Figure 7: a) Impact wear in dependence of different substrate heat treatment and used steel, b) hardness depending on the heat treatment, c) fracture toughness depending on the heat treatment

treatment that resulted in lowest hardness $(\mathrm{C} 2 \mathrm{~N})$ resulted in the highest impact wear.

A material's hardness has long been erroneously used as a criterion for wear resistance. Two materials having different microstructures can have identical hardness values can have significantly different wear rates. This is clearly seen if we compare samples A1 and B1, which have similar hardness ( $\approx 66 \mathrm{HRc}$ ) but have significantly different wear rates. As it was reported by Moore et al., the material microstructure has a greater influence on the wear resistance than the bulk hardness. ${ }^{30}$ Assuming that the harder the material, the greater the wear resistance is technically correct, but cannot be used generally. With some degree of caution, hardness may still be used for the same chemical compositions of the steel. The results clearly show that instead of only hardness, the chemical compositions and the resulting metallurgical structures should also be taken into account.

With the use of SEM and EDS, all the wear craters were analysed, which confirmed that for all cases the main wear mechanism was abrasion. In Figure 8a it can be seen that the wear is gradual and without any evident coating cracking or delamination observed inside the impacted wear scar. If the substrate was too soft to be able to support the coating, the impact wear could exceed the coating thickens (Figure 8b). When this happened, the hardness was again playing a critical role since the substrates with lower hardness resulted in higher wear (B2 > B1).
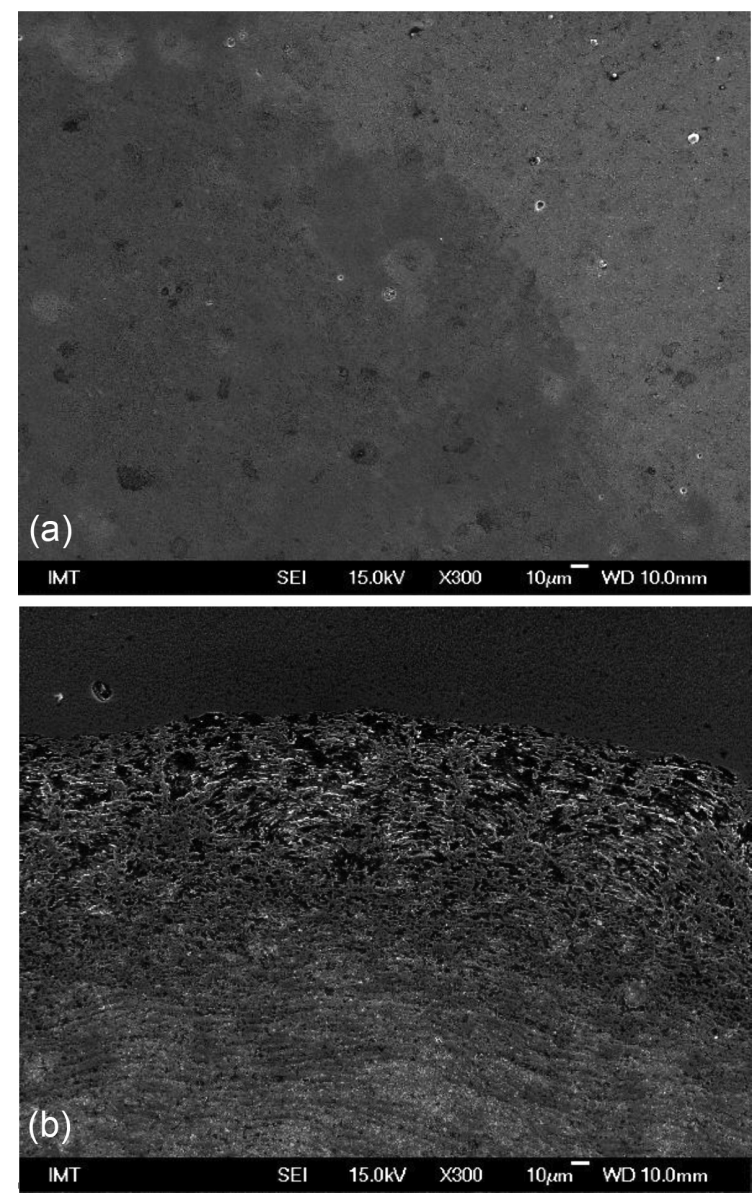

Figure 8: SEM micrograph of the wear crater for: a) sample A1, b) C2 


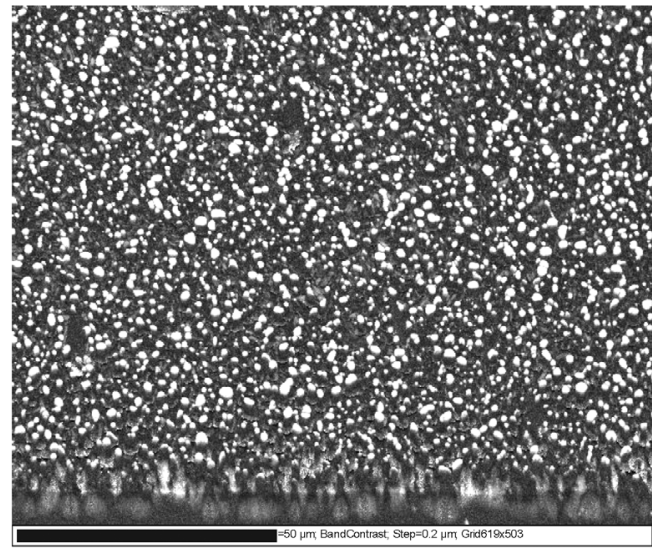

Figure 9: Band contrast EBSD map. The bright globular features are carbides, and the martensitic matrix exhibits poorer diffraction.

To better understand the subsurface deformation, EBSD studies were performed on selected specimens. Figure 9 shows the results of EBSD mappings of the
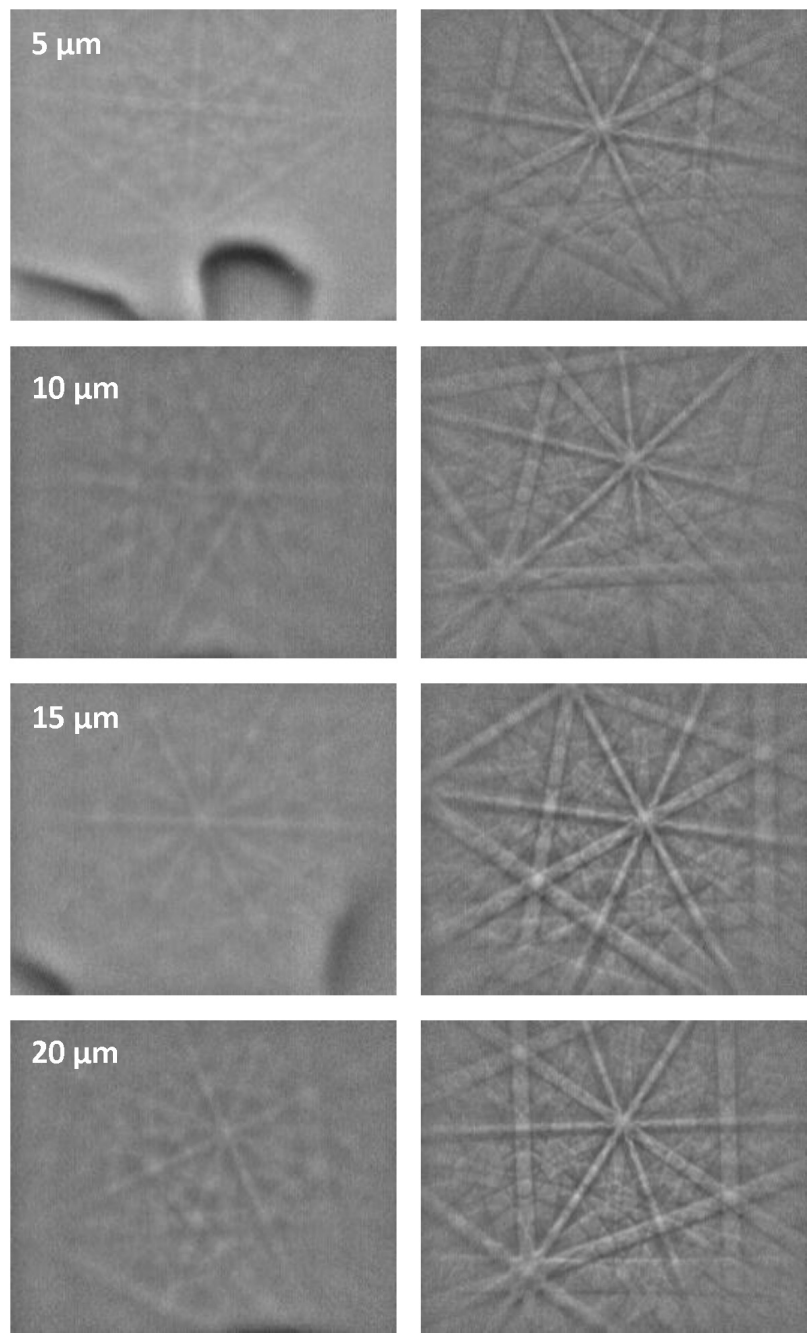

Figure 10: Kikuchi patterns taken at different distances from the surface. Left column: martensite diffractions, right column: carbide diffractions
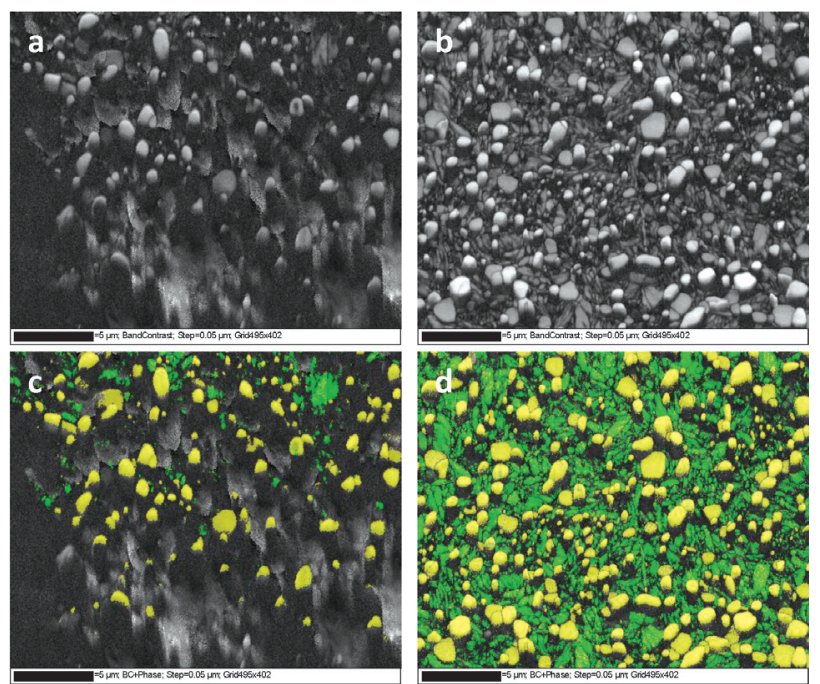

Figure 11: EBSD maps: a,c) region directly below the surface; b,d) recorded at approximately $2 \mathrm{~mm}$ above the impact point

subsurface region of specimen B3. The map size is $123.8 \mu \mathrm{m} \times 100.6 \mu \mathrm{m}$, acquired at step size of $0.2 \mu \mathrm{m}$. The image presents a band contrast map, a measure of the contrast of the Kikuchi pattern. The carbides have sharp diffractions and seem largely unaffected by the impact, while the martensitic matrix has much poorer diffractions, hinting at large deformations of the crystalline lattice. The coating shows no diffraction, meaning that it is most likely amorphous.

The diffraction patterns from the carbides and the martensite matrix taken at different locations below the surface are shown in Figure 10. As J. Perret et al. have shown, the diffractions directly below the impact are too poor to be recognized, due to distorted metal crystalline lattice. $^{31}$

To better understand the situation near the impact, EBSD maps of higher magnification were recorded. Figure 11 shows two such maps: the map in Figures 11 a and 11c represents a region directly below the surface, and the map in Figure 11b and 11d has been recorded at approximately $2 \mathrm{~mm}$ above the impact point. The upper images are band contrast maps, and the lower images are phase maps, with yellow representing the carbide phase and green representing the martensitic phase. No postprocessing noise filtering has been applied. The image sizes are $24.75 \mu \mathrm{m} \times 20.1 \mu \mathrm{m}$.

The images recorded just below the impact show signs of wear: the pattern quality is poor for the martensitic matrix, and because of that the indexing is also quite bad. We can observe little detail of the microstructure of the matrix. Even the carbides seem affected in the zone approximately up to $5 \mu \mathrm{m}$ from the impact. On the other hand, the map recorded about $2 \mathrm{~mm}$ above the impact shows no signs of damage, and we can clearly see the martensitic microstructure in the pattern quality map.

All this leads us to believe that the damage is concentrated in the sub-surface zone, the affected zone is 
approximately $5 \mu \mathrm{m}$ from the surface, and the damage is mostly concentrated in the martensitic matrix.

\section{CONCLUSIONS}

With the combination of a vacuum heat treatment and a deep cryogenic treatment in liquid nitrogen an improvement in the fracture toughness from $10 \%$ to $67 \%$ can be achieved, while maintaining a high hardness for cold-work tool steel A. For high-speed steel C the improvement in the fracture toughness is less pronounced (4\% to $10 \%$ ). When, on the other hand, for cold-work tool steel B a deep cryogenic treatment has a negative influence on the fracture toughness, decreasing it by up to $10 \%$.

Regarding the static load-carrying capacity, the most important property of the substrate is its hardness, with the working hardness of 63-64 HRc already providing excellent static load-carrying capacity of the coated substrate. On the other hand, the increase in fracture toughness achieved by the deep cryogenic treatment improves the static load-carrying capacity only for the case where the hardness of the substrates is too low, below $63 \mathrm{HRc}$.

In terms of dynamic impact wear resistance of the coated surface, the hardness of the substrate still has the greatest impact. The higher the hardness of the substrates, the higher wear resistance of the coated surface can be expected for the material with lower content of carbon. For cold-work tool steels A and B an adequate impact resistance is achieved when hardness of $65 \mathrm{HRc}$ and fracture toughness of $10 \mathrm{MPa} \cdot \mathrm{m}^{1 / 2}$ is reached. For high-speed steel $\mathrm{C}$ the best impact wear resistance is achieved when the hardness is above $65 \mathrm{HRc}$ and additional nitriding in plasma was used. The deep cryogenic treatment and associated increase in fracture toughness has a negative effect for cases when the substrate has a very high hardness and a low toughness or a high fracture toughness but too low hardness. On the other hand, in the case of vacuum heat treatment that ensures an adequate working hardness of 63-64 HRC, the deep cryogenic treatment leads to an improved impact wear resistance of the coated surface. The wear resistance then becomes equal to the case where the substrate with a high hardness is used, but at the same time providing more than $50 \%$ higher fracture toughness required for proper fatigue resistance of the tool. The results also clearly show that instead of only hardness, the chemical compositions and the resulting metallurgical structures should also be taken into account.

\section{Acknowledgment}

Dr. M. Čekada from the Jožef Stefan Institute, Ljubljana, Slovenia, is greatly acknowledged for the help and the deposition of the TiAlN coating.

\section{REFERENCES}

${ }^{1}$ J. A. Schey, Tribology in Metalworking: Friction, Lubrication and Wear, Oxford Publishing, Oxford 1984

${ }^{2}$ A. Gåård, Wear in sheet metal forming; PhD thesis, Karlstad University Studies, Karlstad 2008

${ }^{3}$ R. Ebara, K. Takeda, Y. Ishibashi, A. Ogura, Y. Kondo, S. Hamaya, Microfractography in failure analysis of cold forging dies, Engineering Failure Analysis, 16 (2009) 6, 1968-1976, doi:10.1016/ j.engfailanal.2008.10.023

${ }^{4}$ S. Subramonian, T. Altan, B. Ciocirlan, C. Campbell, Optimum selection of variable punch-die clearance to improve tool life in blanking non-symmetric shapes, International Journal of Machine Tools and Manufacture, 75 (2013) 63-71, doi:10.1016/j.ijmachtools. 2013.09.004

${ }^{5}$ Y. Torres, S. Rodriguez, A. Mateo, M. Anglada, L. Llanes, Fatigue behavior of powder metallurgy high-speed steels: fatigue limit prediction using a crack growth threshold-based approach, Materials Science and Engineering A, 387 (2004) 501-504, doi:10.1016/ j.msea.2003.12.072

${ }^{6}$ V. Leskovšek, B. Šuštaršič, G. Jutriša, The influence of austenitizing and tempering temperature on the hardness and fracture toughness of hot-worked H11 tool steel, Journal of Materials Processing Technology, 178 (2006) 1-3, 328-334, doi:10.1016/j.jmatprotec. 2006.04.016.

${ }^{7}$ V. Leskovšek, B. Podgornik, M. Jenko, A PACVD duplex coating for hot-forging applications, Wear, 266 (2009) 3-4, 453-460 doi:10.1016/j.wear.2008.04.016

${ }^{8}$ L. Lu, Q. Wang, B. Chen, Y. Ao, D. Yu, C. Wang, Microstructure and cutting performance of CrTiAlN coating for high-speed dry milling, Transactions of Nonferrous Metals Society of China, 24 (2014) 6, 1800-1806, doi:10.1016/S1003-6326(14)63256-8

${ }^{9}$ F. Sergejev, P. Peetsalu, A. Sivitski, M. Saarna, E. Adoberg, Surface fatigue and wear of PVD coated punches during fine blanking operation, Engineering Failure Analysis, 18 (2011) 71689-1697, doi:10.1016/j.engfailanal.2011.02.011

${ }^{10}$ B. Podgornik, S. Hogmark, O. Sandberg, Proper coating selection for improved galling performance of forming tool steel, Wear, 261 (2006) 15-21, doi:10.1016/j.wear.2005.09.005

${ }^{11}$ V. Leskovšek, B. Podgornik, Vacuum heat treatment, deep cryogenic treatment and simultaneous pulse plasma nitriding and tempering of P/M S390MC steel, Materials Science and Engineering: A, 531 (2012) 119-129, doi:10.1016/j.msea.2011.10.044

${ }^{12}$ N. Popandopulo, L. T. Zhukova, Transformation in high speed steels during cold treatment, Met. Sci. Heat Treat., 22 (1980) 10, 708-710, doi:10.1007/BF00700561

${ }^{13}$ B. Podgornik, F. Majdič, V. Leskovšek, J. Vižintin, Improving tribological properties of tool steels through combination of deep-cryogenic treatment and plasma nitriding, Wear, 288 (2012) 88-93, doi:10.1016/j.wear.2011.04.001

${ }^{14}$ B. Podgornik, V. Leskovšek, Microstructure and origin of hot-work tool steel fracture toughness deviation, Metall Mater Trans A, 44 (2013) 694-702, doi:10.1007/s11661-013-1921-6

${ }^{15}$ G. Prieto, W. R. Tuckart, J. E. Perez Ipiña, Influence of a cryogenic treatment on the fracture toughness of an AISI 420 martensitic stainless steel, MTAEC9, 51 (2017), 591, doi:10.17222/mit.2016.126

${ }^{16}$ P. Hedenqvist, M. Olsson, S. Jacobson, S. Söderberg, Failure mode analysis of TiN-coated high speed steel, In situ scratch adhesion testing in the scanning electron microscope, Surface and Coatings Technology, 41 (1990) 31-49, doi:10.1016/0257-8972(90)90128-Y

${ }^{17}$ M. Bayramoglu, H. Polat, N. Geren, Cost and performance evaluation of different surface treated dies for hot forging process, J. Mater. Process. Technol., 205 (2008) 394-403, doi:10.1016/ j.jmatprotec.2007.11.256

${ }^{18}$ I. Campos, M. Farah, N. López, G. Bermúdez, G. Rodríguez, C. Villa Velázquez, Evaluation of the tool life and fracture toughness of 
cutting tools boronized by the paste boriding process, Appl. Surf. Sci., 254 (2008) 2967-2974, doi:10.1016/j.apsusc.2007.10.038

${ }^{19}$ T. Atkins, Toughness and processes of material removal, Wear, 267 (2009) 1764-1771, doi:10.1016/j.wear.2009.04.010

${ }^{20}$ B. Podgornik, V. Leskovšek, B. Arh, The effect of heat treatment on the mechanical, tribological and load-carrying properties of PACVD-coated tool steel, Surface and Coatings Technology, 232 (2013) 528-534, doi:10.1016/j.surfcoat.2013.06.019

${ }^{21}$ M. Panjan, M. Čekada, P. Panjan, F. Zupanič, W. Kölker, Dependence of microstructure and hardness of TiAlN/VN hard coatings on the typ of substrate rotation, Vacuum, 86 (2012) 6, 699-702, doi:10.1016/j.vacuum.2011.07.052

${ }^{22}$ B. Ule, V. Leskovšek, B. Tuma, Estimation of plain strain fracture toughness of AISI M2 steel from precracked round-bar specimens, Engineering Fracture Mechanics, 65 (2000) 559-572, doi:10.1016/ S0013-7944(99)00105-8

${ }^{23}$ V. Leskovšek, B. Ule, B. Liščić, Relations between fracture toughness, hardness and microstructure of vacuum heat-treated high-speed steel, Journal of Materials Processing Technology, 127 (2002) 298-308, doi:10.1016/S0924-0136(02)00280-7

${ }^{24}$ Verein Deutscher Ingenieure Normen, VDI 3198, VDI-Verlag, Dusseldorf, 1991

${ }^{25}$ P. Baldissera, D. Delprete, Deep cryogenic treatment: A bibliographic review, Open Mech. Eng. J., 2 (2008) 1-11, doi:10.2174/ 1874155X00802010001
${ }^{26}$ G. Gavriljuk, W. Theisen, V. V. Sirosh, E. V. Polshin, A. Kortmann, G. S. Mogilny, Yu. N. Petrov, Ye. V. Tarusin, Low-temperature martensitic transformation in tool steels in relation to their deep cryogenic treatment, Acta Mater., 61 (2013) 1705-1715, doi:10.1016/ j.actamat.2012.11.045

${ }^{27}$ B. Podgornik, I. Paulin, B. Zajec, S. Jacobson, V. Leskovšek, Deep cryogenic treatment of tool steels, Journal of Materials Processing Technology, 229 (2016) 398-406, doi:10.1016/j.jmatprotec.2015. 09.045

${ }^{28}$ D. Duh, I. Schruff, Optimized heat treatment and nitriding parameters for a new hot-work tool steel, Proccedings of $6^{\text {th }}$ International tooling conference, Karlstad, 2002, 479-495

${ }^{29}$ C. Zhang, T. Hu, N. Zhang, Influence of substrate hardness on coating-substrate adhesion, Adv. Mater. Res., 177 (2010) 148-150, doi:10.4028/www.scientific.net/AMR.177.148

${ }^{30} \mathrm{M}$. A. Moore, The relationship between the abrasive wear resistance, hardness and microstructure of ferritic materials, Wear, 1 (1974) 28 , 59-68, doi:10.1016/0043-1648(74)90101-X

${ }^{31}$ J. Perret, E. Boehm-Courjault, M. Cantoni, S. Mischler, A. Beaudouin, W. Chitty, J.-P. Vernot, EBSD, SEM and FIB characterisation of subsurface deformation during tribocorrosion of stainless steel in sulphuric acid, Wear, 269 (2010) 383-393, doi:10.1016/j.wear. 2010.04.023 